\title{
Application of Green Chemistry: A Miniaturized Procedure for Analysis of Dissolved Phosphate
}

\author{
Nadia Kamal and Clay Runck \\ Department of Biological Sciences \\ Benedictine University \\ 5700 College Road \\ Lisle, Illinois 60532 USA
}

Received: December 18, 2003

Accepted: July 20, 2004

\begin{abstract}
The objective of this study was to determine if the volume of sample used for analysis of soluble reactive phosphate (SRP) could be reduced from $100 \mathrm{~mL}$ (as per a widely used standardized procedure) to 50 or $10 \mathrm{~mL}$ to reduce the amount of hazardous waste generated from routine analysis of SRP in water samples from rivers, streams, and ponds in an urbanized landscape, in accordance with the principles of "green chemistry" and the Pollution Prevention Act of 1990. The ascorbic acid-molybdate blue method of Murphy and Riley (1962) was used to determine the concentration of SRP in water samples collected from the East Branch of the DuPage River and from two ponds on the campus of Benedictine University. Mean concentration of SRP determined using a $10 \mathrm{~mL}$ sample volume of DuPage River water $\left(\bar{x}=1,051 \mu \mathrm{g} \mathrm{PO}_{4} \mathrm{P} / \mathrm{L}\right)$ was significantly greater than the 100 and $50 \mathrm{~mL}$ sample volumes, which were not significantly different from each other $(\bar{x}=1,002 \mu \mathrm{g} \mathrm{PO}-\mathrm{P} / \mathrm{L})$; however, the difference in SRP concentration between $10 \mathrm{~mL}$ and 100 and $50 \mathrm{~mL}$ sample volumes was only $5 \%$. There was no significant effect of sample volume on SRP concentration for slough or storm water pond samples, but these two pond systems had a low SRP concentration $(<3 \mu \mathrm{g} \mathrm{PO}-\mathrm{P} / \mathrm{L})$. The relationship between absorbance and SRP concentration in the ascorbic acid-molybdate blue method was examined between 0 and 2,000 $\mu \mathrm{g} \mathrm{PO}_{4}-\mathrm{P} / \mathrm{L}$; absorbance was asymptotic between 500 and 2,000 $\mu \mathrm{g} \mathrm{PO}_{4^{-}}$ $\mathrm{P} / \mathrm{L}$. The results of this study show that the sample volume for analysis of SRP in DuPage River water with the ascorbic acid-molybdate blue method can be reduced by $50 \%$ (i.e., reduced from $100 \mathrm{~mL}$ to $50 \mathrm{~mL}$ ) without loss of accuracy, but that samples must be diluted to reduce the concentration of SRP to within the limits of the procedure. The reduction in sample volume represents a substantial reduction in the volume of hazardous waste that is generated, and the overall cost per sample, for routine analysis of SRP in the DuPage River.
\end{abstract}

\section{INTRODUCTION}

Phosphorus is a major component in the metabolism of the biosphere, but because it is the least abundant of the major nutritional and structural components of biota (e.g., carbon, nitrogen, oxygen, sulfur), it commonly limits primary production in aquatic systems [1-3]. There are several different forms of phosphorus in aquatic systems, such as dissolved and particulate forms, and inorganic and organic forms. Soluble reactive phosphorus (SRP), also referred to as orthophosphate, is a dissolved form of inorganic phosphate $\left(\mathrm{PO}_{4}{ }^{3-}\right)$ that is the most readily utilized form of phosphorus by algae [2], and it is routinely measured to assess the nutrient status and water quality in aquatic systems [2].

The ascorbic acid-molybdate blue method [1] is a standard procedure for analysis of SRP in freshwater [3, 4]. For 
concentrations from 10 to $500 \mu \mathrm{g} \mathrm{PO}_{4}-\mathrm{P} / \mathrm{L}$, the ascorbic acid-molybdate blue method uses a sample volume of $100 \mathrm{~mL}$. In most natural systems that are not subjected to phosphorous enrichment from human sources, SRP concentrations typically are less than $50 \mu \mathrm{g} \mathrm{PO}_{4}-\mathrm{P} / \mathrm{L}$ in lakes and less than $25 \mu \mathrm{g} \mathrm{PO}-\mathrm{P} / \mathrm{L}$ in rivers [2], so a sample volume of $100 \mathrm{~mL}$ generally has enough SRP in it to be detectable with the ascorbic acid-molybdate blue method. However, concentrations of SRP in freshwater systems that are enriched by phosphorus from human sources often exceed the recommended limits of the ascorbic acidmolybdate blue procedure. In these circumstances, samples must be diluted to lower the SRP concentration to within the limits of the procedure.

The purpose of this study was to determine if the ascorbic acid-molybdate blue method could be modified to reduce sample volume, in order to reduce the quantity of hazardous wastewater that is generated without affecting accuracy or precision. Benedictine University builds its educational life and efforts based on the values St. Benedict put forth in Rules for Monks. One of the Benedictine values is dedication to responsible stewardship of the earth. The principle of responsible stewardship for the environment is the main tenet of "green chemistry", which is incorporated in the Pollution Prevention Act of 1990 [5]. The Pollution Prevention Act of 1990 established a national policy to prevent or reduce pollution at its source. The principles and practices of green chemistry seek to reduce or even eliminate the usage or generation of toxic reagents and solvents while designing chemical products and performing chemical processes, and to prevent waste $[5,6]$. The reagents used in the ascorbic acid-molybdate blue procedure contain the heavy metals antimony $(\mathrm{Sb})$ and molybdenum (Mo), so the wastewater from the SRP analysis is hazardous and costly to dispose of. Reducing sample volume would reduce the volume of hazardous waste that is generated and the associated costs for reagents and waste disposal.

Because the concentration of SRP in the East Branch DuPage River is high (approximate mean $=1,700 \mu \mathrm{g} \mathrm{PO}_{4} \mathrm{P} / \mathrm{L}$, [5]), a smaller sample volume of DuPage River water should contain enough SRP for detection by the ascorbic acid-molybdate blue method. Three sample volumes (10, 50 , and $100 \mathrm{~mL}$ ) were tested in this study to determine if sample volume could be reduced without sacrificing accuracy of the procedure. We also investigated the response of the ascorbic acid-molybdate blue procedure to SRP concentrations higher than recommended, to see if exceeding the method's concentration range had a significant effect on the results. In other words, we were interested in whether the limits of the procedure could be extended to include the range of SRP concentrations in the DuPage River without affecting the accuracy of the results.

\section{PROCEDURE}

Water samples were collected from the East Branch DuPage River at Maple Avenue in Lisle, IL (DuPage County), and from a storm water retention pond and a natural pond (i.e., slough) on the campus of Benedictine University. The East Branch of the DuPage River is located approximately $32 \mathrm{~km}$ west of downtown Chicago and flows through one of the most densely populated counties (DuPage County) in the western suburbs of the Chicago area. At base flow conditions, SRP concentrations in the East and West Branches of the DuPage River average approximately $1,700 \mu \mathrm{g} \mathrm{PO}_{4}-\mathrm{P} / \mathrm{L}$, but can range from 800 to $8,000 \mu \mathrm{gO}_{4}-\mathrm{P} / \mathrm{L}$ [7], far in excess of the upper limit of the ascorbic acid-molybdate blue method (i.e., < $\left.500 \mu \mathrm{PO}_{4}-\mathrm{P} / \mathrm{L}\right)$.

One-liter water samples $(n=5)$ were collected from each water body in early October of 2003. Water samples were returned to the lab and filtered within 1 hour of collection through a glass fiber filter (Whatman $^{\mathrm{TM}} \mathrm{GF} / \mathrm{C}, 47 \mathrm{~mm}$ diameter, pore size $=1.2 \mu \mathrm{m}$ ) followed by filtration through a membrane filter (Millipore ${ }^{\mathrm{TM}}, 47 \mathrm{~mm}$ diameter; $0.45 \mu \mathrm{m}$ pore size). Both types of filters were pre-soaked in distilled deionized water, to leach any phosphate from the filter materials, and air dried before use.

Sample volumes of 100,50 , and 10 $\mathrm{mL}$ were all withdrawn from the same sample and analyzed for SRP using the ascorbic acid-molybdate blue method of Murphy and Riley [1], following the procedure described by Wetzel and Likens [3], with proportional adjustments for reagent 


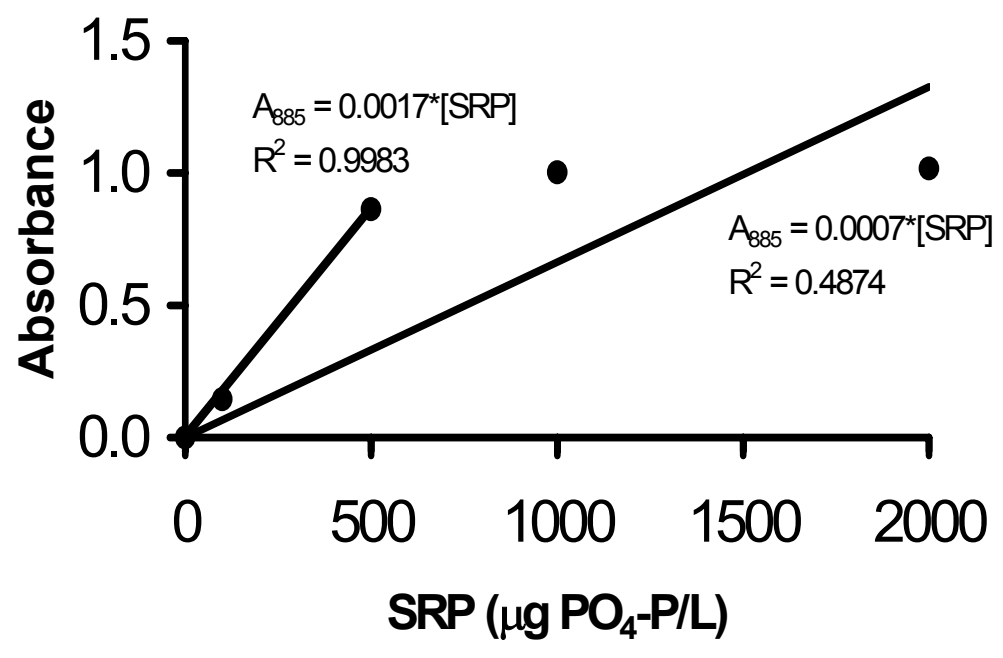

Figure 1. Standard curve for soluble reactive phosphate (SRP) using $0,100,500,1,000$, and $2,000 \mu \mathrm{g} \mathrm{PO}_{4}-\mathrm{P} / \mathrm{L}$ standards.

volume to sample volume ratio. The molybdenum reacts with SRP to produce a blue color and the absorbance of the sample-reagent solution is measured spectrophotometrically. The ascorbic acidmolybdate blue method of Murphy and Riley [1] is applicable in a range of 1 to $500 \mu \mathrm{g}$ $\mathrm{PO}_{4}-\mathrm{P} / \mathrm{L}$, with a precision level of $\pm 1 \mu \mathrm{g} / \mathrm{L}$.

Absorbance (at $885 \mathrm{~nm}, 1 \mathrm{~cm}$ path length) was measured over a range of SRP concentrations to determine if the ascorbic acid-molybdate blue method conformed to Beer's Law over the concentrations tested. Beer's Law states that the amount of light of a specific wavelength absorbed by a solution is linearly proportional to the concentration of the solution, according to the equation $A=e c L$, where $e=$ extinction coefficient, $c=$ concentration, $L=$ length of light path, and $A=$ absorbance. The concentrations of SRP used in the standard curve were $0,100,500,1,000$, and $2,000 \mu \mathrm{g}$ $\mathrm{PO}_{4}-\mathrm{P} / \mathrm{L}$. Concentrations higher than the standard range of the ascorbic acidmolybdate blue method, i.e., 1,000 and $2,000 \mu \mathrm{g} \mathrm{PO}_{4}-\mathrm{P} / \mathrm{L}$, were included to see if the relationship between absorbance and concentration was linear. If the relationship between absorbance and concentration is linear beyond $500 \mu \mathrm{g} \mathrm{PO}_{4}-\mathrm{P} / \mathrm{L}$, then the DuPage River water samples would not need to be diluted prior to analysis for SRP.
One-way analysis of variance (ANOVA) was used to compare the effect of sample volume on phosphorus concentration. The Tukey test was used to compare among treatment (volume) means when ANOVA detected a significant treatment effect [8]. A $t$-test was used to compare mean SRP concentrations between samples from the slough and storm water pond. All statistical analyses were performed using SPSS [9] and all data are reported as mean \pm one standard deviation (SD).

\section{RESULTS}

\section{a. DuPage River Samples}

The relationship between absorbance and SRP concentration was not linear above $500 \mu \mathrm{g} \mathrm{PO}-\mathrm{P} / \mathrm{L}$ (Figure 1). Absorbance reached an asymptote and leveled off above $500 \mu \mathrm{g} \mathrm{PO}_{4}-\mathrm{P} / \mathrm{L}$. The correlation coefficient, $\mathrm{R}^{2}$, was 0.9983 for the regression line from 0 to $500 \mu \mathrm{g} / \mathrm{L}$, but $R^{2}$ was only 0.4874 for the regression line from 0 to 2,000 $\mu \mathrm{gPO}_{4}-\mathrm{P} / \mathrm{L}$. The slopes of the two regression lines differed by a factor of 2.4 , so the $0-2,000 \mu \mathrm{mg} \quad \mathrm{PO}_{4}-\mathrm{P} / \mathrm{L}$ regression equation underestimated the concentration of SRP by 2.4-times. 


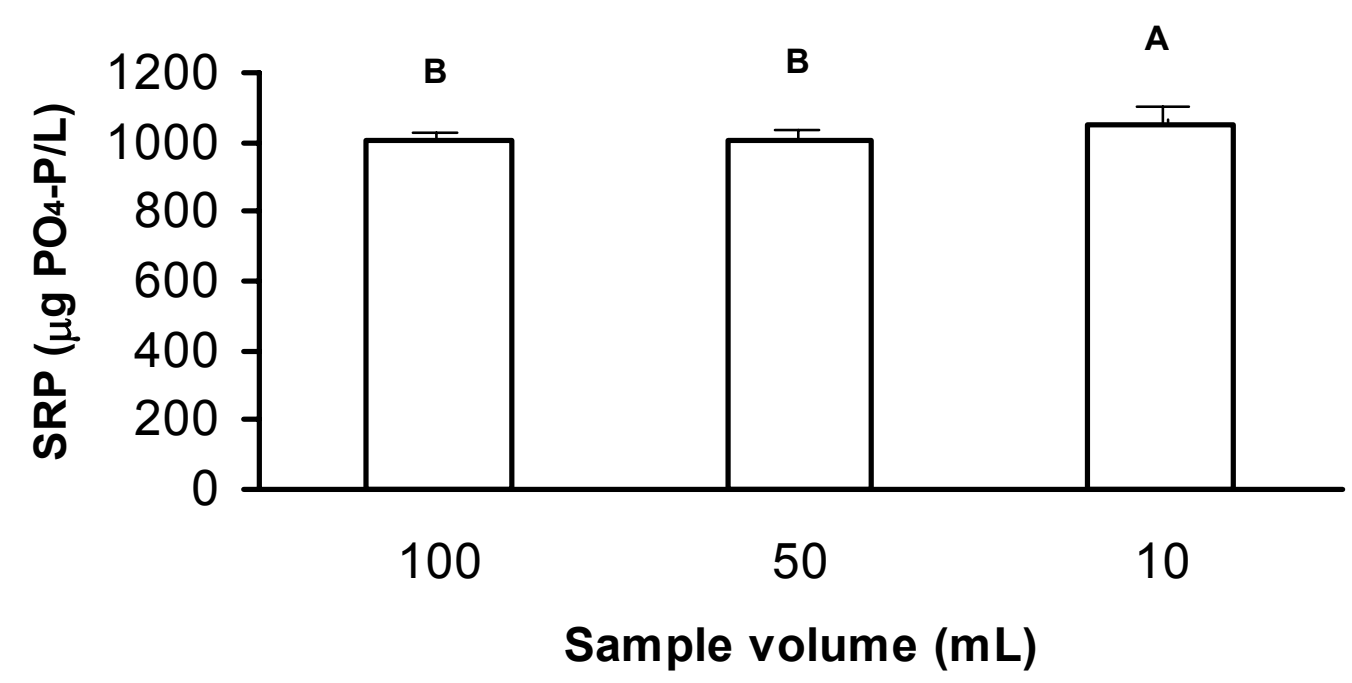

Figure 2. Mean concentration ( $\mu \mathrm{g} \mathrm{PO}_{4}-\mathrm{P} / \mathrm{L}$ ) of soluble reactive phosphorus (SRP) in DuPage River water samples of 100,50 , and $10 \mathrm{~mL}$ calculated by [SRP] $=A_{885} / 0.0017$. Bars with the same letter are not significantly different (Tukey-test, $p>0.05$ ).

There were significant differences in mean SRP concentrations among the three sample volumes tested using DuPage River water (Figure 2; $F_{2,12}=97.467, p<0.001$ ). There was no significant difference in SRP concentration in 100 and $50 \mathrm{~mL}$ sample volumes, which had the same mean SRP concentration $\left(1,002 \mu \mathrm{g} \mathrm{PO}_{4}-\mathrm{P} / \mathrm{L}\right)$. SRP concentration of the $10 \mathrm{~mL}$ sample volume $\left(\bar{x}=1,051 \mu \mathrm{g} \mathrm{PO}_{4}-\mathrm{P} / \mathrm{L}\right)$ was significantly greater than 100 and $50 \mathrm{~mL}$ sample volumes (Tukey-test), but the difference amounted to only $5 \%$.

\section{b. Slough and Storm water Pond Samples}

There were no significant differences in mean SRP concentration among sample volumes for either slough samples $\left(F_{2,12}=1.200, p=0.335\right)$ or among storm water pond samples $\left(F_{2,12}=0.222, p\right.$ $=0.804$ ) (Figure 3). The mean SRP concentration of slough samples (combined mean for three sample volumes $=1.7 \mu \mathrm{g}$ $\left.\mathrm{PO}_{4}-\mathrm{P} / \mathrm{L}\right)$ was $29 \%$ higher than storm water pond samples $\left(1.2 \mu \mathrm{g} \mathrm{PO}_{4}-\mathrm{P} / \mathrm{L}\right)$, but this difference was not statistically significant $\left(\mathrm{t}_{0.05(2), 26}=1.955, \mathrm{p}=0.061\right)$, and SRP concentrations in both systems were near the lower detection limit $\left(1 \mu \mathrm{g} \mathrm{PO}_{4}-\mathrm{P} / \mathrm{L}\right)$ of the ascorbic acid-molybdate blue method.

\section{DISCUSSION}

The results of this study show that the sample volume for SRP analysis can be reduced from $100 \mathrm{~mL}$ to $50 \mathrm{~mL}$ for water samples from the DuPage River without a significant reduction in accuracy. The mean SRP concentration determined for a $10 \mathrm{~mL}$ sample volume of DuPage River water was significantly greater than for 100 and $50 \mathrm{~mL}$ sample volumes, but the actual difference was only $5 \%$. This result suggests that further testing and greater sample replication may be worthwhile because if a sample volume of $10 \mathrm{~mL}$ can be shown to result in no loss of accuracy for DuPage River samples, then reagent and waste volumes could be reduced by $90 \%$.

The ascorbic acid-molybdate blue method is limited to SRP concentrations less than $500 \mu \mathrm{g} \mathrm{PO}_{4}-\mathrm{P} / \mathrm{L}$. Above $500 \mu \mathrm{g} \mathrm{PO}_{4}$ $P / L$, which is typical of the DuPage River, the relationship between absorbance and concentration is asymptotic, indicating the 


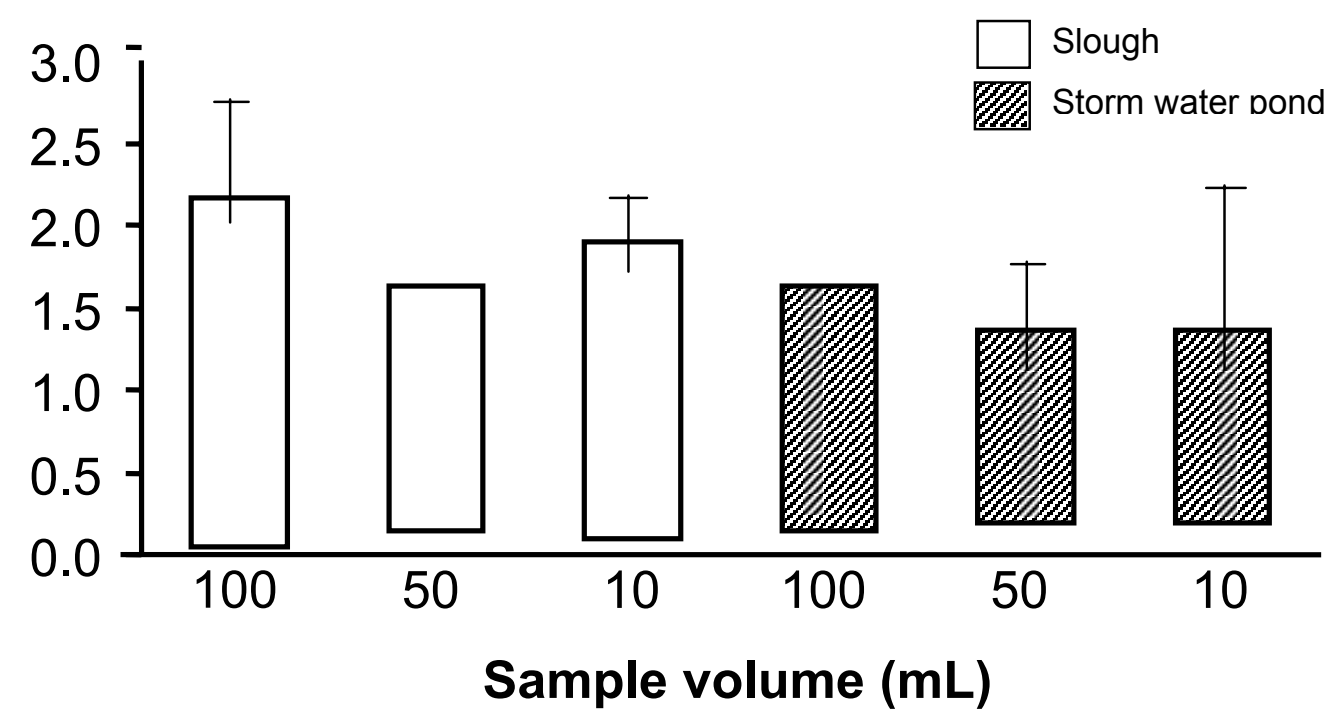

Figure 3. Mean concentration ( $\mu \mathrm{g} \mathrm{PO}_{4}-\mathrm{P} / \mathrm{L}$ ) of soluble reactive phosphorus (SRP) in slough and storm water pond samples of 100,50 , and $10 \mathrm{~mL}$ calculated by $[S R P]=A_{885} / 0.0017$.

reagents were saturated by SRP. DuPage River samples, therefore, must to be diluted to yield a concentration of $<500 \mu \mathrm{g} \mathrm{PO}_{4}-\mathrm{P} / \mathrm{L}$ for the ascorbic acid-molybdate blue method to be accurate.

Results of the SRP analysis of the slough and pond samples indicated that these water bodies are not impacted by SRP loading from the campus grounds. Due to the low concentrations ( $<3 \mu \mathrm{g} \mathrm{PO}-\mathrm{P} / \mathrm{L})$ of SRP in the slough and storm water ponds, a reduction in sample volume is not recommended for water samples with low ( $\left.<10 \mu \mathrm{g} \mathrm{PO}_{4}-\mathrm{P} / \mathrm{L}\right)$ SRP concentration. Thus, one must follow Wetzel and Likens [3] and use a $100 \mathrm{~mL}$ or larger sample volume to provide enough SRP for the colorimetric reaction to produce a sample absorbance that is distinguishable from the blank sample. Furthermore, it would have been more appropriate to use a spectrophotometer cell with a $10 \mathrm{~cm}$ path length instead of a $1 \mathrm{~cm}$ path length, since sensitivity can be increased proportionately with the path length [3].

The reduction in sample volume from $100 \mathrm{~mL}$ to $50 \mathrm{~mL}$ represents a $50 \%$ reduction in the amount of reagents used and in the volume of hazardous waste that is generated. For example, SRP is being monitored monthly at five sites in both the
East and West Branches of the DuPage River. At each site, three water samples are collected and analyzed for SRP; this amounts to 360 samples per year. Using a sample volume of $100 \mathrm{~mL}$ would generate $36 \mathrm{~L}$ of wastewater, whereas sample volumes of 50 and $10 \mathrm{~mL}$ would generate 18 and $3.6 \mathrm{~L}$ per year, respectively (Table 1 ). I calculated that reducing sample volume from $100 \mathrm{~mL}$ to $50 \mathrm{~mL}$ would save $6 \mathrm{~g}$ of molybdenum and $0.09 \mathrm{~g}$ of antimony per year (Table 1).

This study showed that application of the principles of green chemistry can substantially reduce the sample volume necessary for analysis of SRP in two phosphorus-enriched urban rivers without sacrificing accuracy. The reduction in sample volume will result in cost-savings for reagents and wastewater disposal, and more importantly, reduce the potential environmental impacts associated with of the generation and disposal of wastewater containing hazardous elements such as heavy metals.

\section{ACKNOWLEDGEMENTS}

I wish to thank Dr. M. E. Clayton (University of Northern lowa) and two anonymous reviewers for providing helpful 
Table 1. Estimated amounts of reagents used (grams per year, g/y) and wastewater generated (liters per year, L/y) in the analysis of soluble reactive phosphate (SRP) for 100,50 , and $10 \mathrm{~mL}$ samples of river water.

\begin{tabular}{|c|c|c|c|}
\hline Sample volume & $100 \mathrm{~mL}$ & $50 \mathrm{~mL}$ & $10 \mathrm{~mL}$ \\
\hline Wastewater generated $(\mathrm{L} / \mathrm{y})^{+}$ & 36 & 18 & 3.6 \\
\hline Molybdate reagent $(\mathrm{g} / \mathrm{y})$ & 21.6 & 10.8 & 2.16 \\
\hline Molybdenum* $(\mathrm{g} / \mathrm{y})$ & 11.7 & 5.8 & 1.17 \\
\hline Antimony reagent (g/y) & 0.5 & 0.25 & 0.05 \\
\hline Antimony ${ }^{*}(g / y)$ & 0.18 & 0.09 & 0.018 \\
\hline
\end{tabular}

comments that improved the final manuscript. I also thank the Department of Biological Sciences at Benedictine University for tuition assistance from the Dr. Ernest J. Gentchos Scholarship and the PPG Industries Foundation/J. Earl Burrel Scholarship, and funds for reagents and supplies provided, in part, from the Howard Hughes Medical Institute National Sciences Education Summer Research Program to C. Runck.

\section{REFERENCES}

1. Murphy, J. and J. P. Riley. "A modified single solution method for the determination of phosphate in natural waters," Analytica Chimica Acta 27: 3136 (1962).

2. Wetzel, R. G. Limnology, 3rd Edition. (Academic Press, San Diego, CA, 2001).
3. Wetzel, R. G. and G. E. Likens. Limnological Analyses, 2nd Edition (Springer-Verlag, New York, NY. 1991).

4. APHA. Standard Methods for the Examination of Water and Wastewater, $20^{\text {th }}$ Edition. (American Public Health Association, Washington, D.C., 1998).

5. EPA. "Green Chemistry Program Fact Sheet," www.epa.gov/greenchemistry, March 2002.

6. Schoffstall, A. M., B. A. Gaddis, and M. L. Druelinger. Microscale and Miniscale Organic Chemistry Laboratory Experiments, 2nd Edition. (McGrawHill, New York, NY, 2004).

7. Runck, C. unpublished data (Benedictine University, Lisle, IL, USA).

8. Zar, J. H. Biostatistical Analysis, 2nd Edition. (Prentice-Hall, Inc., Englewood Cliffs, NJ, 1984).

9. $\quad$ SPSS. SPSS for Windows, Version 10.0 (SPSS, Inc., Chicago, IL, 1999).

\section{㽞 Benedictine University}

Advancing the liberal arts experience of students is a key component of a Benedictine University education. The College of Arts and Sciences provides this to undergraduates through its major and minor programs, interdisciplinary offerings and support for the core curriculum. At the graduate level, the College offers master's degrees in clinical psychology and clinical exercise physiology. 